\title{
THE AMERICAN CHEMIST AND THE WAR'S PROBLEMS.*
}

JAMES R. Withrow.

A volume could be written upon this subject if one possessed the power to assemble the material. The new problems which have arisen; the old ones which have become acute because of changed conditions; the splendid way in which the problems have been met where they were a matter of invention or skill; the new methods and processes which have sprung up as though born fullgrown; the many old ones which have been improved, altered and utilized in new connections; the way in which the chemists of the country have risen to emergencies which have compelled them to manufacture products in whose manufacture they had had no prior experience, would easily fill entire chapters in such a volume. Even so, no earthly progress, achievement or consideration can lift the pall which settles over us when we permit our minds to dwell upon the spectacle of this war. And whose mind can be diverted from it for any length of time? He must indeed exist far below the kindling-point who does not resent and despise with all his soul, the philosophy and ideals which made it possible. It would be out of place therefore, to consider our subject from the point of view of achievement, or felicitation, on any alleged good which has come to the science of chemistry because of the war. Surely no one would want progress at such a cost to his fellow man. We approach the subject rather in a spirit of thankfulness that we have been enabled to save something out of the wreck, and that our experience had prepared us in advance so that we have been enabled to prevent the collateral business and economic tragedies of the war from spreading universally. It is not in any spirit of gladness, therefore, at the evil providence which has fallen upon our European neighbors, that we recognize that this war has exalted the importance of chemistry in the minds of those who had not much opportunity hitherto to appreciate its value, nor is it with any jubilation that we take pleasure as chemists in meeting our new problems and emergencies arising from the war.

* Address before Section C, American Association for the Advancement of Science, Columbus Meeting, Dec. 30, 1915. 
The satisfaction to many Industrial Chemists in the last two years of being able to contribute to the solution of these problems and of being conscious of the salvation of many businesses from financial ruin through the exercise of their chemical experience, has seldom been so widely distributed as it now is. What an inspiration it would be to read, spread out upon the pages of such a book, as we have mentioned, the chemical successes, big or little, of the past two years. It is not likely that many of them will be known for a while because of the fact that business caution forbids their publicity in many cases, and the vigorous campaign of destruction of equipment and diversion of supplies which stoops at nothing which will hamper export from this country, makes silence a necessity in self defence.

The problems of the war are of two kinds, those due to changed conditions and those arising from supplying munitions at high speed. Among the former are changes in raw materials made necessary by the failure of imports or by unusual consumption of raw material in other channels such as for products not heretofore manufactured in this country to the extent made necessary under present war conditions. These changed circumstances were also due in part to new demands for materials and products, which have arisen in the complete rearrangement of things that has come about in many circles since the war began. The other line of war problems which have arisen, those directly connected with munitions supply, are frequently of a difficult nature. All these various problems, however, have been met in practically every case with a degree of success which has surprised even ourselves.

Naturally one of the first serious effects of the war on American industries was the stagnation produced by the enforced cessation of exports in various lines. Such things as rosin, turpentine, petroleum products, acetate of lime and methyl alcohol were seriously affected for a varying length of time. Then the demand for munitions became, for instance, the wood distillation industry's salvation and with great celerity, acetone plants were attached to many of the works of this industry and the high prices which the products of the industry demanded have brought unprecedented prosperity to it and have correspondingly hampered progressive improvement. 
Production, not efficiency, is at present the slogan for this and many other industries. Set-backs of the nature cited usually take time for readjustment and frequently the chemist is a material factor therein. The producer himself is often compelled to add the next manufacturing step to his own operations. The acetate maker for instance, tends to enter acetone manufacturing. Where the new demands were ample, these attempts have succeeded and the war's conclusion will find an increased tendency to manufacture at the source.

The set-backs to industry arising from the disturbance in exports while they were important financially were minor matters compared with those arising from such changed conditions as failure of raw materials or their curtailment by absorption in new or abnormally expanded industries. It is here that the chemist is needed most and it is here that he has been of immeasurable service, and has met the problems that have arisen in wonderful style. He was seriously hampered at first by the uncertainty as to the facts. The fundamental thing in every industry is the market. At first much damage was wrought and delay produced by false reports as to stocks on hand and supply, particularly, of imports. Much withholding of goods for higher prices was practiced and even yet the pirates of commerce seek ways and means of evading contracts, even on deliveries of goods which they were receiving without cessation, so as to avail themselves of the inflated market prices. Some clever work by consumers trapped at least some of these unscrupulous brokers and sellers. All manner of fictitious prices were demanded of those unfamiliar with the facts and attempts were even made to influence the Washington Government to activity against the British blockade through the use of untruthful statistics regarding dyes.

As soon as the true status of market and supply became reasonably certain many changes were effected which will give gradual and probably ultimate relief. On every hand we see chemical activity without end. Products like synthetic phenol and barium salts not made in this country before the war are now made in large amount. Great expansion in production has taken place in the case of such material as benzol, toluol, aniline products, naphthaline, carbon-tetra-chloride, acids, alkalis, chlorates, bichromates and even oxalic acid. With all of these we were largely or in part dependent on imports, but have 
almost ceased to be so since the war began. Fertilizer plants erect their own sulfuric acid works and insecticide makers their own arsenic acid plants. Textile mills make their own bleach. Numbers of manufacturers replace potash compounds by sodium compounds and to my own surprise at least, often with great improvement in results. Professor Watts has just told you this afternoon how the ceramist is rendering this country less and less dependent upon imports in that field by scientific purification and utilization of domestic clays. Manufacturers of numerous miscellaneous chemicals and pharmaceutical preparations proceed to refine and produce their own crude raw materials and intermediates. The dye faminefor it is real in certain quarters, stirs up corporations with capital of hundreds of millions to enter the field. One of these new companies has installed half a million worth of machinery in the last few weeks. Indigo and other dyes are being made in nearly half ton batches which will soon expand to several ton size. Where formerly was the most peaceful of occupations even fertilizer manufacture, every effort now goes to the making of munitions. New plants spring up at the beck and call of the new conditions such as the world has never seen. Think of a battery of one hundred nitric acid stills each charging 4,000 lbs. of sodium nitrate three times a day. Think of the sulfuric acid required and the nitric acid produced. Think of the fact that this one of a number such, (the largest nitric acid plant in the world it is said), is a plant which a year ago did not exist except in the minds and plans of a group of chemical engineers. How little are we able to comprehend the reality of producing $1,000,000$ pounds per day of gun-cotton where a year ago was merely pine-woods. What does it mean with reference to design of plant, erection and operation to anyone who has not managed chemical engineering operations, to recount the engineering operations involved in this enormous production of gun-cotton in a single plant? Work that is conducted in ten to fifteen parallel procedures or "cottonlines," which with their accompanying accessories, include cleaning and alkali digestion of the cotton; bleaching with chloride of lime; manufacture of sulfuric acid for the production of nitric acid and "mixed acid;" nitration of the cotton in thirty pound batches; the hazardous wringing and hasty submerging of the cotton in water, to avoid the consequences of 
heating by too slow dilution of the strong acid held spongelike by the cotton; the conveying of this material in the cotton-line to the washers where the remaining acid in the tube-shaped cotton fibres is removed; and finally the removal from the water as wet or damp gun-cotton, the commercial product of many plants. This end product of course is but the beginning or raw material for the various nitro-celluloses, smokeless powders and other high explosives. Yet this scale of operations is not going on in just one plant of this kind or even in this one industry. This is a sample of what is happening every day in the shape of the American chemical engineers' answer to the question, how are you meeting the war's problems?

At some of these things we are permitted to take at least a peep. No one man can know all of even such gross developments, and practically every chemist we meet has his enthusiastic story of the progress in his own and familiar fields. We all do know, however, that if this is the character of the outward developments, there must be legions of quiet research and other experimental attacks on the new problems, and literally hundreds of solutions being worked out for minor problems in factory and plant, not to speak of the vast amount of work in other departments of chemistry made necessary by all these things. Then, too, there is the ever verdant crop of interesting suggestions, revolutionary changes and inventions throughout the list of the chemical industries. In fact they are doubly numerous and aggressive under the stimulation of such a time as this. It is never wise to predict their success or failure until even years have elapsed in many cases. So that the lecturer who wishes to entertain his hearers with pleasant and surprising intellectual gymnastics in the shape of the newest and most wonderful achievements in industrial chemistry is safe from apparent error for from three months to three years, if he picks his illustrations well. At the end of that time he can dodge criticism for misjudgement by referring the back-fires to poor business management, insufficient capital, tariff, trusts and sometimes poor engineering. It is true that a large number of these new things never make good. It is equally true that some of them will make good and that all of them indicate progress, for they are striving, and progress comes by striving.

It is equally true also that many of the chemical experiments which are in successful use under war conditions, will auto- 
matically step aside when normal conditions resume. It is fundamental industrial chemical intelligence that a procedure which is ridiculous under some conditions may be a God-send under others. We do not expect every change installed to be really normal progress for it will not be so in the ordinary sense at least. On the other hand, it would be wrong also to say that the mushroom plants producing munitions are not signs of progress. They unquestionably are not such signs in as far as they are temporary. They do not measure true expansion in their respective fields. He would be a novice or singularly blind, however, who did not see that the construction of such plants on the undreamed scale I have already mentioned, not to talk of the new materials and procedures which have been incorporated into many of them, makes for greatly enlarged experience in chemical engineering designing, construction and operation. It is easy to see the pressure these things are going to exert upon the future development of American chemical industries. The American chemist's experience is becoming greatly expanded and the significance of this is apparent when we consider that engineering progress is a function of demand, and skill or experience in solving problems. The demand increment is ever expanding with the development of the country. In addition the skill acquired in the production of munitions is a valuable potential asset for defense should such a necessity ever arise. Such preparedness is highly to be desired. Then too at the close of the war when the output of these plants is no longer needed for that purpose, their equipment and intelligence will be directed into whatever field promises most. Already some of these concerns are assured that some of their products will find a continuous demand after munitions' manufacturing ceases, which will be some little time after actual hostilities are at an end. The field of dye production is already attracting some of them. Without doubt the industrial rearrangements to follow the war will leave us much better situated in our ability to cope with the problems of chemical production. At any rate powerful financial interests will attack these problems as they never have been attacked before. These interests will constitute another great force, which will be particularly effective after the war. When they seek new outlets for materials, such as alcohol, benzol and acids, whose production they are greatly 
accelerating at the present, the gasoline and other problems will be greatly affected. These interests will be found after the war lined up behind the industrial chemists who have been struggling for years against all kinds of unfair competition and disreputable depreciation. Then again, any change in process, be it ever so time-worn, chemistry or transient in its nature, if it actually is put into successful operation under the then existing conditions, must of necessity push out the boundaries of experience to greater and greater distances and make us better able to meet the problems of the future. Chemical engineering is like any other division of engineering, it grows by what it accomplishes. In this proof of ability to meet a transient emergency the American chemist is certainly reaping a hundred-fold, from his unadvertized care in the meeting of his industrial problems of the years which have gone before. Individual cases of progress and development which I have mentioned it is easily seen are rarely of great importance in themselves. We have not been revolutionizing on a great scale, nor have we been jumping at once into great new national industries, but we are rather directing the normal steady gait of our progressive industrial development with keener perception toward more complete selfcontainedness, and thorough industrial preparedness. Some of the industries mentioned which receive much public attention are of relatively little importance compared with many other items affected. The dyestuff shortage appears to annoy many, but the complaint is out of all proportion to the facts and the damage done, compared with that of other commodities. We import annually for instance, $\$ 9,000,000$ in coal tar dyes per annum and if we should make them all ourselves-which we will only gradually approximate-we would only increase our chemical manufactures two per cent. and our total manufactures five onehundredths of one per cent.

Though we have made reasonable headway on our problems we are keenly aware that much remains to be done. We do not expect to set the market right in the dye or other matters in a year or two. These developments take time and have always taken time. Neither should we deceive ourselves or the public into thinking because of what we are doing that we could turn out without the most careful and detailed previous planning, 
adequate munitions for our own defense "in sixty days" to supply the "two million men who would spring to arms" as we so often hear would happen in that undesired emergency.

It would be interesting to discuss in detail some of the transient as well as probably permanent advances, where they happen to be a matter of personal knowledge, if it were wise to hand information to the assassins who lie in wait to hamper some of them, for military reasons. It might be well, therefore, to spend just a little time in emphasizing some general considerations which are connected with this subject.

There is little use in attempting to disguise the fact that the present war is a struggle between the industrial chemical and chemical engineering genius of the Central Powers and that of the rest of the world. Quite irrespective of the war's origin, aims, ideals or political circumstances, these are the cohorts from which each side derives its power.

When we consider the strategic position of the Central Powers themselves, their capable education and training, their system of government, which, no matter what we may think of its selfish effect on the world as a whole, we must admit makes for more effective concentration upon its own governmental objectives, among which preparation for war is merely one of its manifestations, when we take into account all these things it must often appear to us that the greatest outstanding feature of the past two years is the miracle of the Entente Powers resistance to the terribly efficiently prepared onslaught of the Central Powers. This resistance is due, to an extremely large extent, to the efficiency of the chemists of the neutral and Entente nations. The chemists of the Entente Powers and of America have risen to the emergency as no chemists have ever done before in the history of the world. Confronted at the beginning of the war by antagonists whose munitions industry for years had been developed for just such a contingency, these chemists have in less than two years built up a rival industry at least as strong. Plant after plant has sprung up of such perfection of design and operation that one wonders how the mind of man was capable of such engineering. Though the speed with which these new and unexpected problems have been solved may appear surprising, no one who is informed about the progress and development of industrial chemistry in this 
country, could have reason to doubt that American chemical engineers and industrial chemists would rise to any emergency which it was within human power to meet. They have already and will continue to live up to what we have a right to expect of them, in view of their past successes. We would be surprised if a similar degree of success did not crown the efforts of the chemists of the other countries, France, Britain, Italy, Germany, Austria, Russia, for it has never been the habit of American chemists to boastingly claim superiority because of any advantage, real or imaginary, with which they, like any group, are apt to be blessed for a greater or less period of time. We have always appreciated chemical contributions to progress from whatever source they have come and praised unstintingly the individual wherever he may be who has taken a distinct step forward, for we firmly believe this is an important help in advancing the progress of the science.

These general developments are naturally not a matter of public information, except attention is called to them. The chemist works almost entirely beneath the surface of things and only in a few spectacular cases is public attention drawn to his work. It is quite natural therefore that appreciation and praise of foreign chemical achievement and particularly our consistent praise of German achievement to our students by our university teachers of chemistry have been misunderstood, and have prepared a fertile field for foreign propagandas to establish a false impression of the superiority of certain groups of foreign chemists. We would scarcely object to a good-natured adulation of anyone's fatherland and its achievements. Such things always contain good and are stimulating to everyone, and it is a pleasure to hear them when free from arrogance, even when the adulation contains little that is new or even strictly true. When, however, this privilege is abused so that the point of superiority must be made by depreciating American efforts it has a vicious positive result upon the minds of the uninformed, and at times causes great financial loss to them.

If the shortcomings of American chemistry were frankly discussed and compared with foreign successes in a chemical publication, some help might thereby be given to those who could derive benefit from it. When this is not frankly done, but simply issued as an incidental depreciation of American 
chemistry, particularly when discussing foreign chemical achievement, and still worse when in a non-chemical publication, the object can scarcely be rated as creditable.

A good illustration of this is an article published by the Review of Reviews for August, 1915, upon "What German chemists are doing to make Germany self-sustaining," by Hugo Schweitzer, who the editor humanely states is an American chemist. Considering the avowed purpose of the article as attempting to influence American public opinion to stop "all exports to all belligerent nations," the article gives an interesting appreciation of the German chemist's efforts to meet their present problems, but commences to wind up as follows:

"Thus the horrors of war, through the ingenuity of the German chemists, are promoting the legitimate industry of the nation, rendering it more and more independent of foreign conditions, and keeping in the country vast sums formerly spent for imports. Unfortunately and unexpectedly we cannot record similar advantages for the United States, although we are enjoying peace." The inaccuracy of the last statement we hope is no measure of the truthfulness of the article as a whole. If the myth of the overwhelming industrial chemical superiority of German chemists ever was really believed, in that country, the military forces of the Central Powers at least, must marvel at the reason the supposedly inferior foreign industrial chemists have been able to display such astounding ability and speed in meeting the problems of munitions production, particularly too in countries where governmental mobilization of industries was unknown before the war'and in America at least, still is unknown. At any rate, it has become evident that lack of advertisement is no sign of lack of ability or activity, and that ability to handle science skillfully and powerfully is not confined to any race or nation. We do not feel that there is much to be gained by confuting claims of the chemical superiority, of foreign countries in this and other similar articles for it is curious how this war has developed farsightedness to the extent that such Americans can see only the chemical developments abroad.

I hope I have made it clear that it is the abuse of a privilege against which I speak, and not against individuals, for we do not let such personal attacks affect our regard for individual Germans any more than we allow our opinions on the history 
of the past two years to affect this regard for such individuals. Everyone of us knows Germans who are the most whole-souled and kindly men-who we are grateful to know and who scorn to be guilty of, or take advantage of, such chauvinism. Such depreciations of American efforts will bury themselves, without any assistance from us, and I only emphasize them here to call the attention of teachers of chemistry to the fact that we owe protection to the business community and the public against such misrepresentation. We should never cease our appreciation of foreign chemists of whatever nation, but in addition it is our duty first to inform ourselves and then our students upon what our own chemists have done to solve our problems in this country. We have been able to blame our shirking this duty in the past upon the fact that it was easy to get information about foreign chemical achievement and no one seemed anxious to give publicity to American development. We as teachers have certainly done little to remedy this condition. The American Chemical Society, however, has spread the results of American effort before us and made them accessible in its Journal of Industrial and Engineering Chemistry for the last two years, in the shape of a series of addresses on the chemist's contributions to American industries. There are other addresses in these same volumes profoundly informing along these lines and this is particularly true of the Perkin Medal addresses each year in the same journal. In addition, Professor S. P. Sadtler in the American Journal of Pharmacy for October, 1915 (an address before the National Exposition of Chemical Industries), in giving popular information along this line limits himself entirely to chemical industries originated as well as developed by American chemist and Edgar F. Smith's History of Chemistry in America, but recently issued, should be read by every student of chemistry.

None of this work is in any sense a vain glorious adulation of the chemist as some super-being nor is it an attempt to compete in the questionable game of lauding one nationality above another. It is merely a matter of a belated form of education which our universities and chemists hitherto have largely denied to the American business man, and which he has a right to expect of them. The record is one for which we have good reason to be thankful and, as we teachers no longer have the 
excuse of ignorance about American progress, we are at fault, if the rising generation has not an appreciation of the progress of chemistry in America, commensurate with the high level of its development.

In conclusion then, let us take courage from the fact that though much damage has been done to us and our industries by the war, our efforts at salvage benefit us as experience, power and preparedness. We have seen that the chemists of America have met the war situation well and do not require defense at the hands of anyone. It becomes increasingly evident that business is awakened to the value of chemistry as a. source of power and wealth as business has never had occasion or opportunity to be hitherto. Let us hope also that not only the spectators but also all the combatants may learn, even if impelled by bitter war's experience, to appreciate the worth, each of the other, and that all nations are "made of one blood to dwell on the face of the earth." 